\title{
Curcumin and vinblastine induce apoptosis and impair migration in human
}

\section{cutaneous melanoma cells}

Curcumina e vimblastina causam apoptose e prejudicam a migração celular em células de melanoma cutâneo humano

La curcumina y la vinblastina inducen la apoptosis y alteran la migración en células de melanoma cutáneo humano

Vinícius Leobet Lunkes

ORCID: https://orcid.org/0000-0002-6733-1889 Federal University of Santa Maria, Brazil E-mail: vinicius.medvet@mail.ufsm.br

Taís Vidal Palma

ORCID: https://orcid.org/0000-0003-0351-8879 Federal University of Santa Maria, Brazil E-mail: taisvidalpalma@gmail.com

Vitor Bastianello Mostardeiro ORCID: https://orcid.org/0000-0003-4320-0400

Federal University of Santa Maria, Brazil E-mail: vitormostardeiro@gmail.com

Moisés Henrique Mastella ORCID: https://orcid.org/0000-0001-6990-6079 Federal University of Santa Maria, Brazil

E-mail: mhmastella@gmail.com

Charles Elias Assmann

ORCID: https://orcid.org/0000-0002-3524-3446 Federal University of Santa Maria, Brazil

E-mail: charles.ufsm@gmail.com

Micheli Mainardi Pillat

ORCID: https://orcid.org/0000-0002-6753-6083 Federal University of Santa Maria, Brazil E-mail: mmpilat@gmail.com

Ivana Beatrice Mânica da Cruz ORCID: https://orcid.org/0000-0003-3008-6899 Federal University of Santa Maria, Brazil E-mail: ibmcruz@hotmail.com

Vera Maria Melchiors Morsch

ORCID: https://orcid.org/0000-0002-5381-4556 Federal University of Santa Maria, Brazil E-mail: veramorsch@gmail.com

Maria Rosa Chitolina

ORCID: https://orcid.org/0000-0002-5240-8935 Federal University of Santa Maria, Brazil

E-mail: mariachitolina@gmail.com

Cinthia Melazzo de Andrade

ORCID: https://orcid.org/0000-0002-5579-5344 Federal University of Santa Maria, Brazil E-mail: cmelazzoandrade1@gmail.com

\begin{abstract}
Cancer is an important cause of lethality, and melanoma is associated with less than $10 \%$ of survival. The traditional treatment includes the use of vinblastine, and it is associated with side effects. Curcumin is extracted from Curcuma longa rhizomes, and studied in many diseases, producing a variety of effects. We investigated the role of various cellular pathways concerning apoptosis, cell cycle enzymes in melanoma cell line SK-MEL-28, after treatment with curcumin, vinblastine, or a combination of both, for 24 hours. After this, we performed cell cycle, apoptosis, wound healing assay, comet assay on cells, and evaluated nitrite accumulation (nitric oxide (NO•) byproduct). Curcumin increased cells in apoptosis and reduced the number of cells in the G1 phase. Vinblastine increased the production of nitrite, and cells in early apoptosis, mainly through the inducement of DNA damage. Cell migration was impaired in all tested groups. In conclusion, curcumin impaired migration, producing NO•, and promoting apoptosis of tumoral
\end{abstract}


cells. Vinblastine also impaired cell migration and increased levels of NO•. Curcumin might be included as an adjuvant in the treatment of melanoma, and help treatment of melanoma, and further studies are needed, especially regarding the synergistic effect of curcumin and vinblastine in the treatment.

Keywords: Melanoma; Curcumin; Apoptosis; Migration.

\section{Resumo}

O câncer é uma importante causa de letalidade, e o melanoma está associado a menos de $10 \%$ de sobrevida. O tratamento tradicional inclui o uso de vimblastina e está associado a diversos efeitos colaterais. A curcumina é uma substância extraída dos rizomas da planta Curcuma longa, e estudada em muitas doenças, produzindo uma ampla variedade de efeitos. Nós investigamos o papel de várias vias celulares relacionadas à apoptose, enzimas do ciclo celular na linhagem celular de melanoma SK-MEL-28, após tratamento com curcumina, vimblastina ou uma combinação de ambos, por 24 horas. Após isso, avaliamos ciclo celular, apoptose, migração celular, ensaio cometa nas e avaliamos o acúmulo de nitrito (subproduto de óxido nítrico (NO•). A curcumina aumentou as células em apoptose e reduziu o número de células na fase G1. A vimblastina, por sua vez, aumentou a produção de nitrito e células em apoptose precoce, principalmente através da indução de danos no DNA. A migração celular foi prejudicada em todos os grupos testados. Em conclusão, a curcumina prejudicou a migração, produzindo $\mathrm{NO} \bullet \mathrm{e}$ promovendo a apoptose de células tumorais. Assim, A vimblastina também prejudicou a migração celular e aumentou os níveis de $\mathrm{NO} \bullet$. Assim, a curcumina pode ser incluída como adjuvante no tratamento do melanoma e auxiliar no tratamento do melanoma, sendo necessários mais estudos, principalmente quanto ao efeito sinérgico da curcumina e da vimblastina no tratamento.

Palavras-chave: Melanoma; Curcumina; Apoptose; Migração.

\section{Resumen}

El cáncer es una causa importante de letalidad y el melanoma se asocia con menos del 10\% de supervivencia. El tratamiento tradicional incluye el uso de vinblastina y se asocia con efectos secundarios. La curcumina se extrae de los rizomas de Curcuma longa y se estudia en muchas enfermedades, produciendo una variedad de efectos. Investigamos el papel de varias vías celulares relacionadas con la apoptosis, las enzimas del ciclo celular en la línea celular de melanoma SK-MEL-28, después del tratamiento con curcumina, vinblastina o una combinación de ambos, durante 24 horas. Después de esto, realizamos el ciclo celular, la apoptosis, el ensayo de cicatrización de heridas, el ensayo de cometa en las células y evaluamos la acumulación de nitrito (subproducto de óxido nítrico (NO•)). La curcumina aumentó las células en apoptosis y redujo el número de células en la fase G1. La vinblastina aumentó la producción de nitrito y células en apoptosis temprana, principalmente a través de la inducción de daño en el ADN. La migración celular se vio afectada en todos los grupos analizados. En conclusión, la curcumina perjudicó la migración, produciendo $\mathrm{NO} \bullet$ y promoviendo la apoptosis de las células tumorales. La vinblastina también perjudicó la migración celular y aumentó los niveles de $\mathrm{NO} \bullet$. La curcumina podría incluirse como adyuvante en el tratamiento del melanoma y ayudar al tratamiento del melanoma, y se necesitan más estudios, especialmente en relación con el efecto sinérgico de la curcumina y la vinblastina en el tratamiento.

Palabras clave: Melanoma; Curcumina; Apoptosis; Migración.

\section{Introduction}

Cancer has a high worldwide incidence and lethality (Sung et al., 2021). Melanoma skin cancer is associated with high metastasis and prognostic with metastatic disease is reserved, less than $10 \%$ survival (Gershenwald et al., 2017). With this in mind, it's important to evaluate adjuvant substances, which might help during the treatment. Curcumin (CUR), also known as diferuloylmethane, is a substance extracted from Curcuma longa rhizomes, and extensively studied in many cancer diseases (Willenbacher et al., 2019). It interacts with a high range of proteins and pathways, producing different effects, like inhibition of cell proliferation, invasion, and metastasis (Hassanalilou et al., 2019). CUR causes tumoral inhibition by inducing cell cycle arrest and apoptosis in breast cancer cells ( $\mathrm{Hu}$ et al., 2018). CUR also modulates production of nitric oxide (NO•) and DNA cell damage, as indicated by previous works (Longobardi et al., 2021).

Nitric oxide is a free radical inorganic signaling molecule that is generated via multiple mechanisms, and in melanoma cell lines, the inducible NO• synthase (iNOS) is overexpressed (Grimm et al., 2013; Joshi et al., 1996). Antitumor effects of NO• were also recorded in different human and animal tumors (Choudhari et al., 2013; Vahora et al., 2016), as higher levels of $\mathrm{NO}^{\bullet}$ tend to be cytotoxic to cancer cells. This is achieved by the formation of peroxynitrite, which acts as an 
inducer of apoptosis and other toxic species during immune surveillance.

Vinblastine (VIN) is a chemoterapeutic agent used in treatment of melanoma and other diseases, inhibiting angiogenesis and targeting celular tubulins (Mhaidat et al., 2016), impairing tumoral development and reducting metastatic dissemination. Although vinblastine is a common drug used to treat many types of cancer, it is associated with many side effects, like nausea, vomiting, and headaches (Lee et al., 2015).

Considering the high incidence and lethality of melanoma, the necessity for new adjuvant substances is evident. Thus, the present study investigates the role of cellular pathways regarding apoptosis, cell cycle, DNA damage, cell migration, and NO• accumulation in melanoma cell line SK-MEL-28 treated with CUR and/or VIN.

\section{Methodology}

\subsection{Cell line and cell culture}

SK-MEL-28 human melanoma cell line (ATCC $®$ HTB-72 ${ }^{\mathrm{TM}}$ ) was maintained in DMEM (Dulbecco's Modified Eagle Medium; Life Technologies) culture medium plus $100 \mathrm{IU} / \mathrm{mL}$ penicillin, $100 \mu \mathrm{g} / \mathrm{mL}$ streptomycin and $10 \%$ cell culture tested fetal bovine serum (FBS). The cells were incubated in a cell culture incubator at $37^{\circ} \mathrm{C}, 5 \% \mathrm{CO}_{2}$ atmosphere, and $95 \%$ humidity. The culture medium was renewed 2 to 3 times per week.

\subsection{Preparation of the CUR solution}

A previous study (manuscript in preparation) evaluated the concentration that caused $50 \%$ inhibition of cell viability (IC $\mathrm{I}_{50}$ ) of curcumin as $40 \mu \mathrm{M}$, and therefore that concentration was used in subsequent assays. To compare the effects of CUR to treatment, we used vinblastine (VIN) at $20 \mathrm{nM}$ (Selimovic et al., 2013), and a combination of CUR and VIN (40 $\mu$ M and 20 $\mathrm{nM}$, respectively). The quantity of DMSO in the medium was less than $0.1 \%$.

\subsection{Wound healing assay}

SK-MEL-28 cells were cultured in a 12-well plate. After cells reached almost 100\% confluency, the supernatant was removed, and yellow pipette tips were used to scratch the cell surface. The cells were washed with PBS to remove debris and treated with DMEM (negative control), CUR, VIN, and CUR+VIN for $24 \mathrm{~h}$. The scratched area was photographed with a microscope at $0 \mathrm{~h}$ and $24 \mathrm{~h}$ of treatment. The experiment was repeated twice. The quantification of the results represents three times for cell scratch assays. The area of the scratch of the negative control (DMEM) was set as 100\%, and areas of scratches of treated wells were proportionally compared to control, using ImageJ software.

\subsection{Cell cycle determination}

SK-MEL-28 cells were cultured in 12 -well plates $\left(2 \times 10^{4}\right.$ cells/well). After the treatment with DMEM (negative control), CUR, VIN, and CUR+VIN, supernatants were discarded, and cells were removed from the wells with a trypsin/EDTA solution $(0.2 \% / 0.02 \%)$. The action of the trypsin was neutralized with the addition of a culture medium with $10 \%$ FBS. Subsequently, the samples were centrifuged $(1,500 \mathrm{~g})$, the supernatant was discarded, and the samples were then fixed and permeabilized by adding $75 \%$ ice-cold ethanol. After that, samples were centrifuged, and the pellet was resuspended with $500 \mu \mathrm{L}$ of DNA-staining solution with PBS ( $0.1 \%$ Triton, $0.5 \%$ Tween, $10 \mu \mathrm{g} / \mathrm{mL}$ propidium iodide). The samples were incubated for $1 \mathrm{~h}$ and analyzed in a flow cytometer. 


\subsection{Evaluation of apoptosis by quantification of annexin and propidium iodide by flow cytometry}

For apoptosis assays of SK-MEL-28 cells in the presence of CUR, VIN, or CUR+VIN cultured in 12-well plates $\left(2 \times 10^{5}\right.$ cells/well $)$ were used. After the treatment period, the supernatant was discarded, the cells were removed from the wells with a trypsin/EDTA solution $(0.2 \% / 0.02 \%)$. The action of trypsin was neutralized with the addition of a medium with $10 \%$ FBS. Subsequently, cells were centrifuged, supernatants discarded, and cell pellets were resuspended with $200 \mu \mathrm{L}$ of binding buffer (10 mM HEPES, $140 \mathrm{mM} \mathrm{NaCl}, 2.5 \mathrm{mM} \mathrm{CaCl} 2$ and $1 \mu \mathrm{L}$ Annexin-V; BD Biosciences, CAT: 559763). The samples were incubated on ice for $30 \mathrm{~min}$, plus propidium iodide and immediately analyzed in a flow cytometer.

\subsection{Nitrite in supernatants}

The accumulation of nitrite (a stable end product of $\mathrm{NO} \bullet$ ) in supernatants of control and treated (CUR, VIN, and CUR+VIN) cells was determined using the Griess reagent in 96-well plates. The supernatant was mixed with an equal volume of Griess reagent ( $1 \%$ sulphanilamide, $0.01 \%$ naphthyl ethylenediamine dihydrochloride, and $2.5 \%$ phosphoric acid). The color developed after $15 \mathrm{~min}$ incubation was measured at $540 \mathrm{~nm}$. Absorbance in the untreated control was set to $100 \%$, and absorbance in other wells was proportionally calculated to control.

\subsection{Alkaline Comet Assay}

The alkaline comet assay was performed (Singh et al., 1988) and subsequently stained with silver nitrate technique (Nadin et al., 2001). Briefly, the samples were initially resuspended in $0.7 \%$ low melting point agarose and placed on glass slides previously covered with $1 \%$ agarose, and the slides were dipped into a lysis solution at $4{ }^{\circ} \mathrm{C}$. In the electrophoresis stage, the slides were placed in a horizontal vat and covered with a solution of $1 \mathrm{mM}$ EDTA and $300 \mathrm{mM} \mathrm{NaOH}(\mathrm{pH}>13)$ for $20 \mathrm{~min}$. Then, an electric current of $300 \mathrm{~mA}$ at $25 \mathrm{~V}$ was applied for $20 \mathrm{~min}$. After electrophoresis, the slides went through the stages of neutralization, fixation, and subsequent staining with silver nitrate. For the analysis, a standardized damage score was used, ranging from the lowest damage (0) to the maximum damage (4), and the results were expressed as a damage index relative to the control. The samples were processed in duplicates, and all slides were analyzed by at least two trained observers.

\subsection{Statistical analysis}

Data were analyzed by Graph Pad Prism software (version 6 Prism), one or two-way ANOVA, followed by Tukey's post-hoc test. Differences between mean values were considered significant at $\mathrm{p} \leq 0.05$. Data are shown as mean values $\pm \mathrm{SD}$, a representative for three independent experiments.

\section{Results}

\subsection{CUR and CUR+VIN impair migration of SK-MEL-28 cells}

To verify if CUR and VIN could alter cell migration, a wound-healing assay was performed. CUR or VIN significantly reduced wound area (Figure 1), through inhibition of cell migration. The scratches were significantly $(\mathrm{p}<0.05)$ wider in the CUR and VIN treatments (Figure 1). These results suggest that curcumin significantly inhibited the migration of SK-MEL-28 cells. 
Figure 1. Wound healing assay.

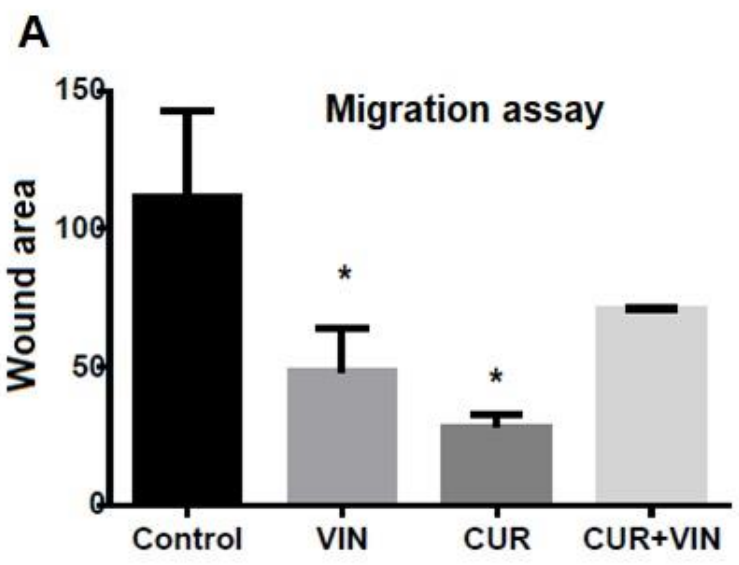

B
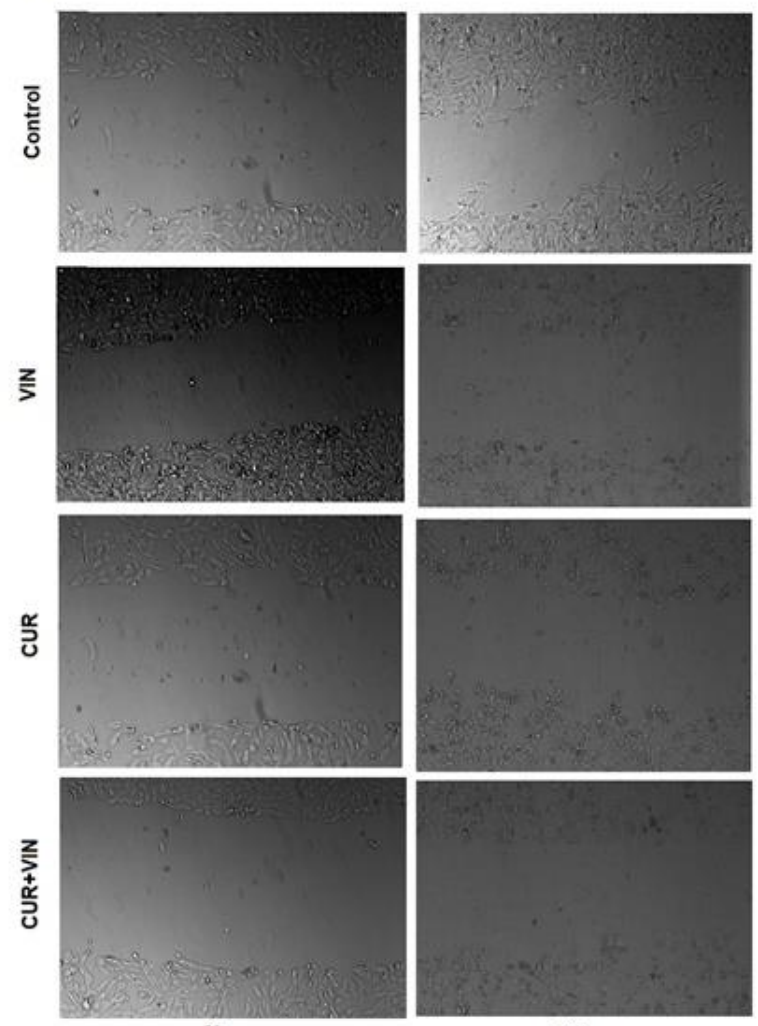

$\mathrm{Oh}$

$24 \mathrm{~h}$

Wound healing assay demonstrated decreased migration of SK-Mel-28 cells after exposure to CUR (40 $\mu$ M) for $24 \mathrm{~h}$, or VIN (20 nM). Data are shown as mean $\pm \mathrm{SD}$, “*”represents a significant difference of $\mathrm{P} \leq 0.05$. (B) Representative images of wound healing assay following exposure of CUR, VIN, and CUR+VIN on SK-MEL-28 cells for 24 hours. wound healing capacity. Magnification, x400. CUR: curcumina; VIN: vinblastine; CUR+VIN: curcumin+vinblastine. Source: Authors.

\subsection{CUR induces cell cycle arrest in the G1-phase of SK-MEL-28 cells}

To determine whether treatments might influence the proliferation of SK-MEL-28, frequencies (\%) of cells in different phases of the cell cycle were determined by flow cytometry (Figure 2A). CUR at a concentration of 40 $\mu \mathrm{M}$ decreased percentages of cells in G1 compared to untreated controls. Percentages of cells in S and G2-phase did not change. 
Figure 2. Assessment of cell cycle and apoptosis.

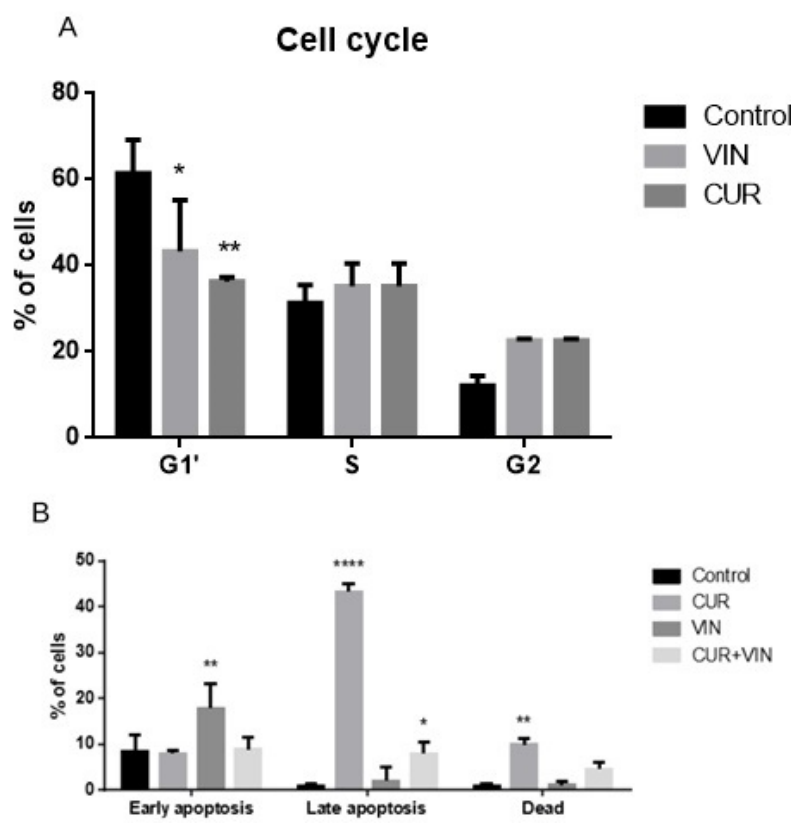

(A) Cell cycle arrest effects of CUR, VIN, and CUR+VIN in SK-MEL-28 cells for 24 hours. Graphs represent the percentage of cell cycle distribution at the G1, S and G2 phases.. Data are presented as the mean \pm SD. "**" and "**" represent a significant difference of $p<0.05$ and ${ }^{* *} \mathrm{p}<0.01$, respectively. (B) . Evaluation of apoptosis after $24 \mathrm{~h}$ of treatment with CUR, VIN, or CUR+VIN in SK-MEL-28 cells for 24 hours. Quantification by flow cytometry of the percentage of cells in apoptosis and cell death. Source: Authors.

\subsection{CUR and CUR+VIN induce apoptotic death in SK-MEL-28 cells}

For evaluation of apoptosis-like cell death, Annexin V and Propidium Iodide (PI) were markers. Vinblastine caused an accumulation of cells in early apoptosis when compared to untreated controls. $40 \mu \mathrm{M}$ of CUR during $24 \mathrm{~h}$ in SK-MEL-28 cells promoted early apoptosis (Annexin+/PI- cells) compared to control samples. Also, there was an increase in cells in late apoptosis (Annexin+/PI+cells) in cells treated with CUR+VIN. Regarding cell death, there was a significant increase in dead cells in cells treated with CUR $(40 \mu \mathrm{M})$ (Figure $2 \mathrm{~B})$.

\subsection{CUR and VIN increased accumulation of nitrite in cell culture medium}

Since nitric oxide is a very unstable molecule, we evaluated the accumulation of nitrite in supernatants, since this substance is stable. After $24 \mathrm{~h}$ of treatment with CUR, VIN or CUR+VIN, supernatants of these cells were collected and nitrite accumulation was measured and compared proportionally to untreated control cell supernatants. In this sense, CUR and VIN significantly increased nitrite in supernatants, compared to untreated controls (Figure 3A). 
Figure 3. Nitrate in the supernatant and DNA damage
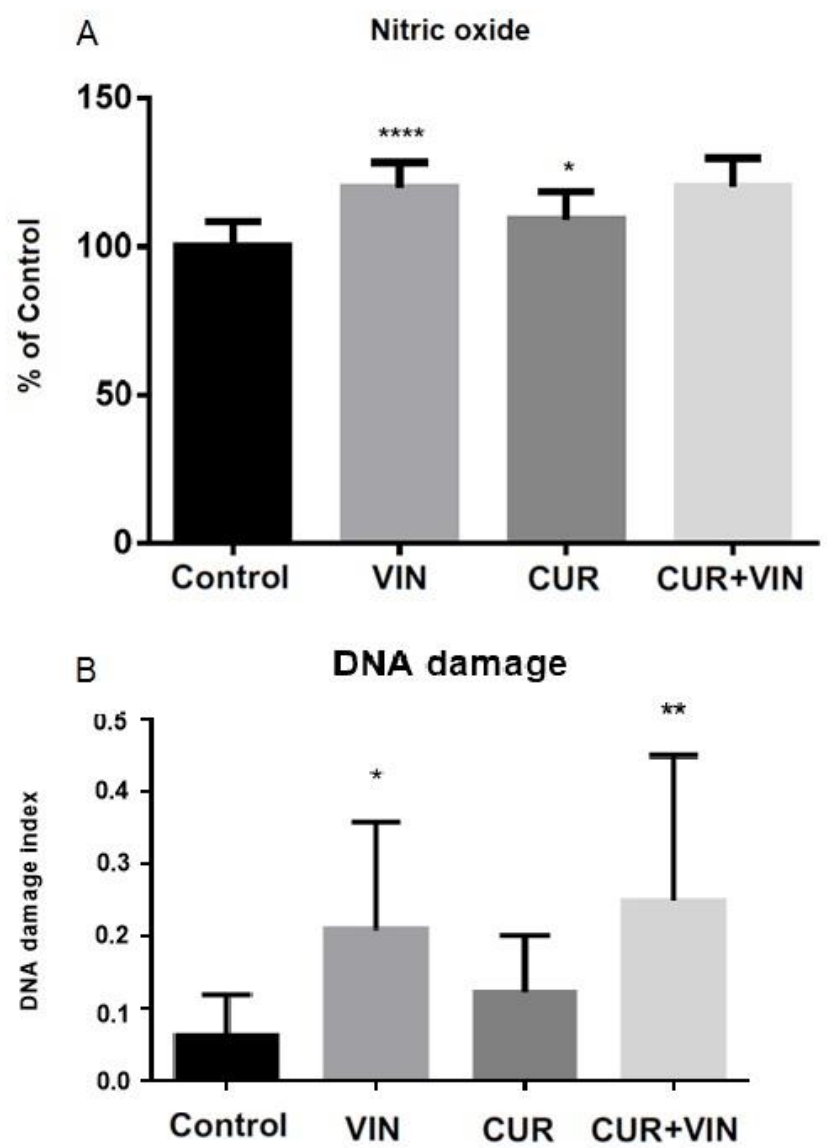

(A) Accumulation of nitrate in the supernatant of cells treated with CUR, VIN, or CUR+VIN for 24 hours. (B) DNA damage of SK-MEL-28 cells treated with CUR, VIN, or CUR+VIN for 24 hours. Data are shown as mean \pm SD, a representative for three independent experiments, “*” and "**" represent a significant difference of $\mathrm{p}<0.05$ and $\mathrm{p}<0.01$, respectively. CUR: curcumina; VIN: vinblastine; CUR+VIN: curcumin+vinblastine. Source: Authors.

\subsection{VIN and CUR+VIN increased DNA damage}

To evaluate DNA damage in melanoma cells treated and untreated, a comet assay was performed. We detected a significant increase in DNA damage in cells treated with VIN and CUR+VIN (Figure 3B).

\section{Discussion}

In 2019, cancer was the second leading cause of death in the world, overcame only by cardiovascular disease (Global Burden of Disease Collaborative Network, 2020). In this context, cutaneous melanoma, despite its low incidence, is a malignant neoplasm with a high degree of metastasis, and low responsiveness to traditional treatments. Recently, several substances used in traditional cookery are being studied as possible adjuvants in the treatment of cancer. Thus, curcumin (CUR), a compound extracted from the rhizomes of Curcuma longa, has been studied in tumor cell cultures of various origins in which it has reduced tumor cell viability and caused cell death by apoptosis, modulating cell signaling pathways (Hu et al., 2018), like in breast cancer, oral cancer, and skin cancer (Paul, Sa, 2021). Our results indicate a possible beneficial effect of curcumin in the SK-MEL-28 melanoma cell line.

Studies in human oral (Zhen et al.,2014), colorectal (Pricci et al., 2020), and cervical (Ghasemi et al., 2019) cancers have shown that CUR induces G2-phase cell cycle arrest. Our results show that CUR treatment resulted in the accumulation of cells in the G2/M phase with the reduction from the G0/G1 phase, so curcumin might have caused cell-cycle arrest at the G2/M 
phase, even though there was no statistical significance. Our results suggest that curcumin could block cells in the $\mathrm{S}$ phase, thus preventing DNA from replicating properly, and inhibiting tumor growth. It has been reported that anticancer agents can arrest the cancer cell cycle regulation at the G0/G1, S, or G2/M phase which leads to the induction of apoptosis (Garrett, Collins, 2011), so we hypothesize that just as happened with VIN, CUR might have promoted the same cell cycle arrest effect in these cells.

To determine if CUR concentration was only preventing stopping the cell cycle, or also causing cell death, we performed an apoptosis assay by flow cytometry. We detected a significant increase in cells in late apoptosis when treated with $40 \mu \mathrm{M}$ CUR for $24 \mathrm{~h}(* * * * \mathrm{p}<0.001)$. Also, cells in early apoptosis increased too when treated with VIN. These results indicate cells died when treated with CUR or VIN.

There was an increase in cells in late apoptosis when treated with a combination of CUR and VIN, so we may hypothesize this combination would also be beneficial to cells. The beneficial effects of the combination of CUR and commonly used cancer therapies might be due to synergistic effects, promoting tumoral cell apoptosis through many pathways (Tan \& Norhaizan, 2019).

In our study, curcumin-induced cell cycle arrest and apoptosis when SK-MEL-28 cells were treated for 24 hours with $40 \mu \mathrm{M}$ of curcumin. Moreover, it induced cell cycle arrest and reduced tumoral cell migration. CUR and VIN impaired cell migration in the scratch assay. The same effect was detected in human osteosarcoma cells treated with vinblastine (Wang et al., 2019). VIN impairs microtubule growth, necessary for cell migration (Dhamodharan et al., 1995). CUR also impairs cell microtubule, inducing arrest at pause state (Banerjee et al., 2010). This emphasizes the importance of the evaluation of CUR in the treatment of melanoma.

To verify if DNA damage could be involved in this apoptosis induction, we performed the alkaline comet assay. Previous studies indicate detrimental effects of VIN in DNA, thus favoring tumoral apoptosis (Tiburi et al., 2002), since cancer is frequently linked to mutations of p53, a known tumor suppressor, mainly through DNA repair and apoptosis (Liu et al., 2014). This way, VIN might have damaged DNA, and promoted apoptosis.

Since nitric oxide $(\mathrm{NO} \bullet)$ is an important substance in the tumoral microenvironment, we measured this substance next. NO• has a very short living and reacts with a wide array of substances, its measurement is challenging, so we measured one of its byproducts, the nitrite. $\mathrm{NO} \bullet$ is a signaling molecule, and its importance relies on free radical formation and activation of signaling pathways (Yarlagadda et al., 2017). Higher levels of NO• may induce DNA damage and cause apoptosis, but lower levels are linked to chemoresistance (Choudhari et al., 2013; Vahora et al., 2016). We detected an increase in nitrite production in cells treated with VIN and CUR. This might indicate an increase in the production of NO• (and its byproduct nitrate). We may hypothesize this increase might be toxic to cancerous cells, promoted DNA damage, and cell death.

\section{Final Considerations}

CUR has important effects, impairing cell migration, producing $\mathrm{NO}^{\bullet}$, and promoting apoptosis of tumoral cells. This indicates CUR might be evaluated as adjuvant compound in treatment of melanoma. In addition, VIN also impaired cell migration and increased levels of $\mathrm{NO}^{\bullet}$. This synergistic effect of CUR and VIN can help in the treatment of melanoma. This sinergism should be studied in next experiments.

\section{Acknowledgments}

This study was financed in part by the Coordenação de Aperfeiçoamento de Pessoal de Nível Superior - Brasil (CAPES) - Finance Code 001. 


\section{References}

Banerjee, M., Singh, P., \& Panda, D. (2010). Curcumin suppresses the dynamic instability of microtubules, activates the mitotic checkpoint and induces apoptosis in MCF-7 cells: Curcumin suppresses microtubule dynamics. The FEBS Journal, 277(16), 3437-3448. 10.1111/j.1742-4658.2010.07750.x

Choudhari, S. K., Chaudhary, M., Bagde, S., Gadbail, A. R., \& Joshi, V. (2013). Nitric oxide and cancer: a review. World Journal of Surgical Oncology, 11(1), 118. 10.1186/1477-7819-11-118

Dhamodharan, R., Jordan, M. A., Thrower, D., Wilson, L., \& Wadsworth, P. (1995). Vinblastine suppresses dynamics of individual microtubules in living interphase cells. Molecular Biology of the Cell, 6(9), 1215-1229. 10.1091/mbc.6.9.1215

Garrett, M. D., \& Collins, I. (2011). Anticancer therapy with checkpoint inhibitors: what, where and when? Trends in Pharmacological Sciences, 32(5), 308316. 10.1016/j.tips.2011.02.014

GBD Results Tool. (n.d.). Retrieved November 18, 2021, from Healthdata.org website: http://ghdx.healthdata.org/gbd-results-tool

Gershenwald, J. E., Scolyer, R. A., Hess, K. R., Sondak, V. K., Long, G. V., Ross, M. I., for members of the American Joint Committee on Cancer Melanoma Expert Panel and the International Melanoma Database and Discovery Platform. (2017). Melanoma staging: Evidence-based changes in the American Joint Committee on Cancer eighth edition cancer staging manual: Melanoma Staging: AJCC 8th Edition. CA: A Cancer Journal for Clinicians, 67(6), 472-492. 10.3322/caac. 21409

Ghasemi, F., Shafiee, M., Banikazemi, Z., Pourhanifeh, M. H., Khanbabaei, H., Shamshirian, A., \& Mirzaei, H. (2019). Curcumin inhibits NF-kB and Wnt//catenin pathways in cervical cancer cells. Pathology, Research and Practice, 215(10), 152556. 10.1016/j.prp.2019.152556

Grimm, E. A., Sikora, A. G., \& Ekmekcioglu, S. (2013). Molecular pathways: inflammation-associated nitric-oxide production as a cancer-supporting redox mechanism and a potential therapeutic target. Clinical Cancer Research: An Official Journal of the American Association for Cancer Research, 19(20), 55575563. 10.1158/1078-0432.CCR-12-1554

Hassanalilou, T., Ghavamzadeh, S., \& Khalili, L. (2019). Curcumin and gastric cancer: A review on mechanisms of action. Journal of Gastrointestinal Cancer, 50(2), 185-192. 10.1007/s12029-018-00186-6

Hu, S., Xu, Y., Meng, L., Huang, L., \& Sun, H. (2018). Curcumin inhibits proliferation and promotes apoptosis of breast cancer cells. Experimental and Therapeutic Medicine. doi:10.3892/etm.2018.6345

Joshi, M., Strandhoy, J., \& White, W. L. (1996). Nitric oxide synthase activity is up-regulated in melanoma cell lines: a potential mechanism for metastases formation. Melanoma Research, 6(2), 121-126. 10.3892/etm.2018.6345

Lee, C.-T., Huang, Y.-W., Yang, C.-H., \& Huang, K.-S. (2015). Drug delivery systems and combination therapy by using vinca alkaloids. Current Topics in Medicinal Chemistry, 15(15), 1491-1500. 10.2174/1568026615666150414120547

Longobardi, C., Damiano, S., Andretta, E., Prisco, F., Russo, V., Pagnini, F., \& Ciarcia, R. (2021). Curcumin modulates nitrosative stress, inflammation, and DNA damage and protects against ochratoxin A-induced hepatotoxicity and nephrotoxicity in rats. Antioxidants (Basel, Switzerland), 10(8), 1239. 10.3390/antiox 10081239

Liu, J., Zhang, C., \& Feng, Z. (2014). Tumor suppressor p53 and its gain-of-function mutants in cancer. Acta Biochimica et Biophysica Sinica, 46(3), 170-179. doi:10.1093/abbs/gmt 144

Mhaidat, N. M., Alzoubi, K. H., Khabour, O. F., Alawneh, K. Z., Raffee, L. A., Alsatari, E. S., \& Bani-Hani, K. E. (2016). Assessment of genotoxicity of vincristine, vinblastine and vinorelbine in human cultured lymphocytes: a comparative study. Balkan Journal of Medical Genetics: BJMG, 19(1), 13-20. 10.1515/bjmg-2016-0002

Nadin, S. B., Vargas-Roig, L. M., \& Ciocca, D. R. (2001). A silver staining method for single-cell gel assay. The Journal of Histochemistry and Cytochemistry: Official Journal of the Histochemistry Society, 49(9), 1183-1186. 10.1177/002215540104900912

Paul, S., \& Sa, G. (2021). Curcumin as an adjuvant to cancer immunotherapy. Frontiers in Oncology, 11, 675923. 10.3389/fonc.2021.675923

Pricci, M., Girardi, B., Giorgio, F., Losurdo, G., Ierardi, E., \& Di Leo, A. (2020). Curcumin and colorectal cancer: From basic to clinical evidences. International Journal of Molecular Sciences, 21(7), 2364. 10.3390/ijms21072364

Selimovic, D., Badura, H. E., El-Khattouti, A., Soell, M., Porzig, B. B. O. W., Spernger, A., \& Hassan, M. (2013). Vinblastine-induced apoptosis of melanoma cells is mediated by Ras homologous A protein (Rho A) via mitochondrial and non-mitochondrial-dependent mechanisms. Apoptosis: An International Journal on Programmed Cell Death, 18(8), 980-997. 10.1007/s10495-013-0844-4

Singh, N. P., McCoy, M. T., Tice, R. R., \& Schneider, E. L. (1988). A simple technique for quantitation of low levels of DNA damage in individual cells. Experimental Cell Research, 175(1), 184-191. 10.1016/0014-4827(88)90265-0

Sung, H., Ferlay, J., Siegel, R. L., Laversanne, M., Soerjomataram, I., Jemal, A., \& Bray, F. (2021). Global cancer statistics 2020: GLOBOCAN estimates of incidence and mortality worldwide for 36 cancers in 185 countries. CA: A Cancer Journal for Clinicians, 71(3), 209-249. 10.3322/caac.21660.

Tan, B. L., \& Norhaizan, M. E. (2019). Curcumin combination chemotherapy: The implication and efficacy in cancer. Molecules (Basel, Switzerland), 24(14), 2527. 10.3390/molecules 24142527

Tiburi, M., Reguly, M. L., Schwartsmann, G., Cunha, K. S., Lehmann, M., \& de Andrade, H. H. R. (2002). Comparative genotoxic effect of vincristine, vinblastine, and vinorelbine in somatic cells of Drosophila melanogaster. Mutation Research. Genetic Toxicology and Environmental Mutagenesis, 519(1-2), 141-149. 10.1016/s1383-5718(02)00136-5 
Research, Society and Development, v. 11, n. 2, e20511225611, 2022

(CC BY 4.0) | ISSN 2525-3409 | DOI: http://dx.doi.org/10.33448/rsd-v11i2.25611

Vahora, H., Khan, M. A., Alalami, U., \& Hussain, A. (2016). The potential role of nitric oxide in halting cancer progression through chemoprevention. Journal of Cancer Prevention, 21(1), 1-12. 10.15430/JCP.2016.21.1.1

Wang, H., Naghavi, M., Allen, C., Barber, R. M., Bhutta, Z. A., Carter, A., \& Murray, C. J. L. (2016). Global, regional, and national life expectancy, all-cause mortality, and cause-specific mortality for 249 causes of death, 1980-2015: a systematic analysis for the Global Burden of Disease Study 2015. Lancet, 388(10053), 1459-1544. 10.1016/S0140-6736(16)31012-1

Wang, X., Decker, C. C., Zechner, L., Krstin, S., \& Wink, M. (2019). In vitro wound healing of tumor cells: inhibition of cell migration by selected cytotoxic alkaloids. BMC Pharmacology and Toxicology, 20(1), 4. 10.1186/s40360-018-0284-4

Willenbacher, E., Khan, S., Mujica, S., Trapani, D., Hussain, S., Wolf, D., \& Seeber, A. (2019). Curcumin: New insights into an ancient ingredient against cancer. International Journal of Molecular Sciences, 20(8), 1808. 10.3390/ijms20081808

Yarlagadda, K., Hassani, J., Foote, I. P., \& Markowitz, J. (2017). The role of nitric oxide in melanoma. Biochimica et Biophysica Acta. Reviews on Cancer, 1868(2), 500-509. 10.1016/j.bbcan.2017.09.005

Zhen, L., Fan, D., Yi, X., Cao, X., Chen, D., \& Wang, L. (2014). Curcumin inhibits oral squamous cell carcinoma proliferation and invasion via EGFR signaling pathways. International Journal of Clinical and Experimental Pathology, 7(10), 6438-6446. https://pubmed.ncbi.nlm.nih.gov/25400722/ 